International Journal of Current Advanced Research

ISSN: O: 2319-6475, ISSN: P: 2319 - 6505, Impact Factor: SJIF: 5.995

Available Online at www.journalijcar.org

Volume 6; Issue 4; April 2017; Page No.3023-3025

DOI: http://dx.doi.org/10.24327/ijcar.2017.3025.0168

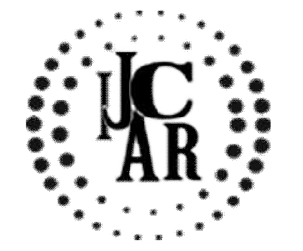

Research Article

\title{
AWARENESS OF ADVANCE STEM CELL THERAPY AMONG STUDENTS- A Survey
}

\author{
Adeline Persia R*., Vishnu Priya V and Gayathri R
}

Saveetha Dental College and Hospitals, Poonamallee, Chennai-77

\begin{tabular}{|c|c|}
\hline 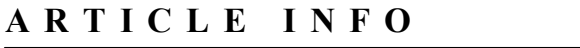 & A B S T R A C T \\
\hline Article History: & \multirow{4}{*}{$\begin{array}{l}\text { Stem cell therapy is the use of stem cell to treat or prevent a disease or condition. Stem cell } \\
\text { therapy extensively explored worldwide to enhance human health in medical setting. } \\
\text { Nevertheless, there is currently no full understanding of the stem cell knowledge attitude } \\
\text { towards stem cell application in medicine, and its association with years of education, } \\
\text { among Saveetha university undergraduate dental students. Stem cell therapy has becomes } \\
\text { controversial following developments such as the ability of scientists to isolate and culture } \\
\text { embryonic stem cell, to create stem cell using somatic cell nuclear transfer and use of } \\
\text { techniques to create induced pluripotent stem cells. This controversy is often related to } \\
\text { abortion politics and to human cloning. Additionally, efforts to market treatments based on } \\
\text { transplant of stored umbilical cord, blood have been controversial. }\end{array}$} \\
\hline $\begin{array}{l}\text { Received } 11^{\text {th }} \text { January, } 2017 \\
\text { Received in revised form } 19^{\text {th }} \text { February, } 2017 \\
\text { Accepted } 22^{\text {nd }} \text { March, } 2017 \\
\text { Published online } 28^{\text {th }} \text { April, } 2017\end{array}$ & \\
\hline Key words: & \\
\hline Stem Cell Therapy, Among Students & \\
\hline
\end{tabular}

Copyright $\mathbb{C} 2017$ Adeline Persia $R$ et al. This is an open access article distributed under the Creative Commons Attribution License, which permits unrestricted use, distribution, and reproduction in any medium, provided the original work is properly cited.

\section{INTRODUCTION}

Stem cells have potential to develop into many different cell types in the body i.e., Stem cells [1] are distinguished generally by their ability to differentiate into many types of cells in the body and to self-replicate indefinitely during early life and growth. Stem cells [2] in many tissues serve as a sort of internal repair system, dividing essentially without limit to replenish other cells as long as the person or animal is still alive. Stem cells [3] are capable of dividing and renewing themselves for long periods unlike muscle cells, blood cells, or nerve cells which do not normally replicate themselves stem cells [4] may replicate many times, or proliferate. A starting population of stem cells that proliferates for many months in the laboratory can yield millions of cells. If the resulting cells continue to be unspecialized, like the parent stem cells, the cells are said to be capable of long-term selfrenewal [5]. Particularly Neural stem cells exist not only in the developing mammalian nervous system but also in the adult nervous system of all mammalian organisms, including humans. Neural stem cells can also be derived from more primitive embryonic stem cells. The location of the adult stem cells and the brain regions to which their progeny migrate in order to differentiate remain unresolved, although the number of viable locations is limited in the adult. Potential uses of stem cells [6] in repair include transplantation to repair missing cells and the activation of endogenous cells to provide "self-repair" [7]. Multipotent stem cells have the same basic features of all stem cells. As with all stem cells [8] multipotent stem cells are unspecialized cells that have the

*Corresponding author: Adeline Persia R

Saveetha Dental College and Hospitals, Poonamallee, Chennai-77 ability to: Self-renew for long periods of time and differentiate into specialized cells with specific functions. A multipotent stem cell can give rise to other types of cells but it is limited in its ability to differentiate. Multipotent stem cells include those in the brain that give rise to different neural cells and glia or hematopoietic cells [9], which can give rise to different blood cell types, but they can't create brain cells. Bone marrow also contains multipotent stem cells that give rise to all blood cell types but not other cells [10].

In general stem cells are classified in three types. They are

- Embryonic stem cells,

- Adult or somatic stem cells,

- Induced pluripotent stem cells or iPSCs.

Embryonic stem cells Embryonic stem (ES) cells are derived from totipotent cells of the early mammalian embryo and are capable of unlimited, undifferentiated proliferation in vitro. Adult or somatic stem cells Adult stem cells are stem cells that can be derived from different parts of the body and, depending on where they are from, have different properties. They exist in several different tissues including bone marrow, blood and the brain. Induced pluripotent stem cells or iPSCs Induced Pluripotent stem cells are often termed 'true' stem cells because they have the potential to differentiate into almost any cell in the body. This means the induced pluripotent stem cells (iPSCs) from somatic cells demonstrates that adult mammalian cell scan be reprogrammed to a pluripotent state by the enforced expression of a few embryonic transcription factors. Stem cell application in medicine Human stem cell research holds an enormous potential to contribute the understanding of fundamental human biology. The introductions of antibiotics and vaccines, for example, have dramatically increased life 
spans and improved the health of people all over the world. The science of stem cell therapies, potentially as important as these other advances, is about to enter a phase of research and development that could lead to unprecedented cures and palliative treatments. Some Examples of Treatments for Major Diseases are like Cancer, Type 1 Diabetes in Children, Nervous System Diseases, Primary Immunodeficiency Diseases, Diseases of Bone and Cartilage.

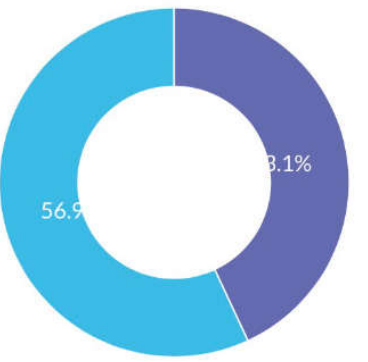

Choices

- Yes

- No

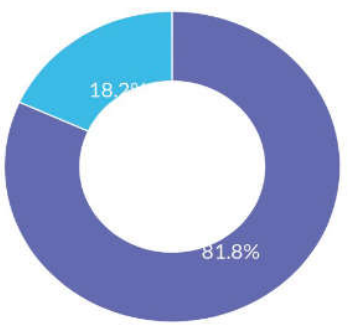

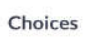

Totals

- Umbilical cord

- Blood

\section{Objective}

The Objective of this study is to determine the awareness of stem cell therapy among students.

\section{MATERIALS AND METHODS}

A descriptive design using survey method was used to determine the awareness of stem cell therapy among students. Subjects were Indians including men and women who were taken as subjects to determine the awareness of stem cell therapy among students. The online questionnaire was related to awareness of stem cell therapy. In this online survey, a total of 70 subjects participated.

Descriptive statistics was used for data analysis. The results were analysed and presented in tables and figures. Data was obtained from the subjects who volunteered to participate in this study.

\section{RESULT AND DISCUSSION}

According to the results the total number of participants in that were 70 The number of participants who selected YES $(82 \%)$ and NO (18\%) for the question "Are you aware of stem cell therapy"?. This shows that $82 \%$ in average are not aware of stem cell therapy, and about $18 \%$ are aware of stem cell therapy and $81.8 \%$ know that the stem cells are taken from the
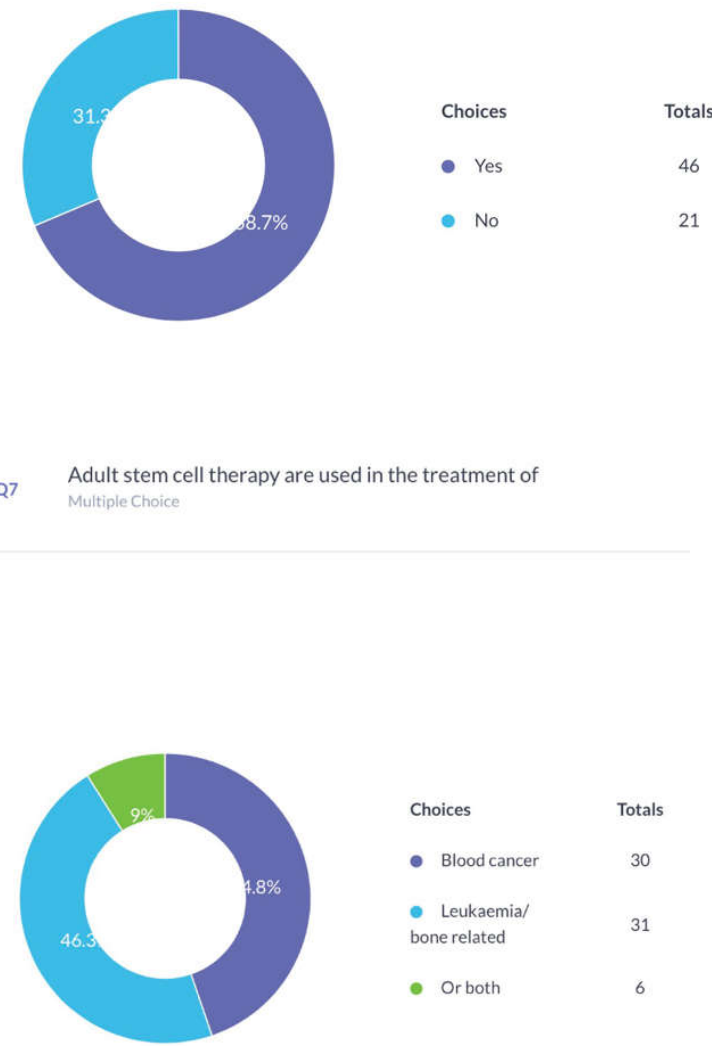

umbilical cord. The subjects, in which $31.3 \%$ didn't know that adult stem cells are also called somatic stem cells and $38.7 \%$ knew that adult stem cells are also called has somatic stem cell. Stem cell therapy is the use of stem cells to treat or prevent a disease or condition. Stem cell therapy extensively explored worldwide to enhance human health in medical setting.

\section{CONCLUSION}

Stem cells have the ability to differentiate into many types of cells in the body and to self-replicate indefinitely during early life and growth. Stem cell can self-renew for long periods of time and differentiate into specialized cells with specific functions. A multipotent stem cell can give rise to other types of cells but it is limited in its ability to differentiate. The benefits to individuals and to society gained by the introduction of new drugs or medical technologies are difficult to estimate. The introductions of antibiotics and 
vaccines had increased life span and improved the health of people all over the world. Despite these and other advances in the prevention and treatment of human diseases such as heart disease, diabetes, cancer, and diseases of the nervous system such as Alzheimer's disease present continuing challenges to the health and well-being of people everywhere. The science leading to the development of techniques for culturing human stem cells could lead to unprecedented treatments and even cures for these and other diseases.

\section{References}

1. Minguell JJ, Pereira A, Bartholomew P and Lasala GP (2011) The Intrathecal Infusion of Mesenchymal Stem Cells into Healthy Rabbits is Safe and Devoid of Neurological or Clinical Complications. J Stem Cell Res Ther 1: 104.

2. Cruz M, Siden $\AA$, Tasat DR, Yakisich JS (2010) Are all Glioma Cells Cancer Stem Cells? J Cancer Sci Ther 2: 100-106.

3. Duran JM, George JC (2011) A Review of the Basis of Autologous Stem Cell Therapy for Coronary Artery Disease. J Clinic Experiment Cardiol 2: 130.

4. Rameshwar P (2011) Post-identification of Cancer Stem Cell: Ethical and Scientific Dilemmas in Therapeutic Development?. J Stem Cell Res Ther 1: e101

http://stemcells.nih.gov/info/basics/basics3.asp
5. Novik AA, Kuznetsov AN, Melnichenko VY, Fedorenko DA, Ionova TI, et al. (2011) Nonmyeloablative Autologous Haematopoietic Stem Cell Transplantation with Consolidation Therapy using Mitoxantrone as a Treatment Option in Multiple Sclerosis Patients. J Stem Cell Res Ther 1: 102.

6. Fred H. Gage (2000) Mammalian Neural Stem Cells. Science 287: 1433-1438.

7. Ghodsizad A, Voelkel T, Moebius JM, Gregoric I, Bordel V, et al. (2010) Biological Similarities Between Mesenchymal Stem Cells (Mscs) and Fibroblasts. $J$ Cytol Histol 1: 101.

8. Porrata LF, Inwards DJ, Ansell SM, Micallef IN, Johnston PB, et al. (2011) Day 15 Peripheral Blood Lymphocyte/monocyte Ratio Postautologous PeripheralHematopoietic Stem Cell Transplantation and Survival in Diffuse Large B-cell Lymphoma. $J$ Stem Cell Res Ther 1: 103.

http://www.explorestemcells.co.uk/multipotentstemcell s.html

9. Meregalli M, Farini A, Torrente Y (2011) Mesenchymal Stem cell as Muscle Resevoir . J. Stem Cell Res Ther 1: 105

10. Suzanne kadereit Adult Stem Cell. International Society for Stem Cell Research.

\section{How to cite this article:}

Adeline Persia R et al (2017) ' Awareness Of Advance Stem Cell Therapy Among Students- A Survey', International Journal of Current Advanced Research, 06(04), pp. 3023-3025.

DOI: http://dx.doi.org/10.24327/ijcar.2017.3025.0168 